\title{
Nitrogen uptake by the shoots of smooth cordgrass Spartina alterniflora
}

\author{
T. J. Mozdzer ${ }^{1,3, *}$, M. Kirwan ${ }^{1,2}$, K. J. McGlathery ${ }^{1}$, J. C. Zieman ${ }^{1}$ \\ ${ }^{1}$ Department of Environmental Sciences, University of Virginia, 291 McCormick Rd, Charlottesville, Virginia 22904, USA \\ ${ }^{2}$ Patuxent Wildlife Research Center, US Geological Survey, 12100 Beech Forest Rd, Laurel, Maryland 20708, USA \\ ${ }^{3}$ Present address: Smithsonian Environmental Research Center, 647 Contees Wharf Rd, Edgewater, Maryland 21037, USA
}

\begin{abstract}
The smooth cordgrass Spartina alterniflora is the foundation species in intertidal salt marshes of the North American Atlantic coast. Depending on its elevation within the marsh, $S$. alterniflora may be submerged for several hours per day. Previous ecosystem-level studies have demonstrated that $S$. alterniflora marshes are a net sink for nitrogen $(\mathrm{N})$, and that removal of $\mathrm{N}$ from flooding tidal water can provide enough $\mathrm{N}$ to support the aboveground biomass. However, studies have not specifically investigated whether $S$. alterniflora plants assimilate nutrients through their aboveground tissue. We determined in situ foliar and stem $\mathrm{N}$ uptake kinetics for ${ }^{15} \mathrm{NH}_{4},{ }^{15} \mathrm{NO}_{3}$, and ${ }^{15} \mathrm{~N}$-glycine by artificially flooding plants in a mid-Atlantic salt marsh. To determine the ecological importance of shoot uptake, a model was created to estimate the time of inundation of $S$. alterniflora in $20 \mathrm{~cm}$ height intervals during the growing season. Estimates of inundation time, shoot mass, N uptake rates, and $\mathrm{N}$ availability from long-term data sets were used to model seasonal shoot $\mathrm{N}$ uptake. Rates of aboveground $\mathrm{N}$ uptake rates (leaves + stems) were ranked as follows: $\mathrm{NH}_{4}{ }^{+}>$glycine $>\mathrm{NO}_{3}{ }^{-}$. Our model suggests that shoot $\mathrm{N}$ uptake may satisfy up to $15 \%$ of the growing season $\mathrm{N}$ demand in mid-Atlantic salt marshes, with variation depending on plant elevation and water column $\mathrm{N}$ availability. However, in eutrophic estuaries, our model indicates the potential of the plant canopy as a nutrient filter, with shoot uptake contributing 66 to $100 \%$ of plant $\mathrm{N}$ demand.
\end{abstract}

KEY WORDS: Foliar uptake $\cdot$ Stem uptake $\cdot$ Ammonia $\cdot$ Glycine $\cdot$ Nitrate $\cdot$ DON Resale or republication not permitted without written consent of the publisher

\section{INTRODUCTION}

North American Atlantic coast salt marshes are dominated by the foundation species Spartina alterniflora (Mitsch \& Gosselink 1993, Pennings \& Bertness 2001). The ability of $S$. alterniflora to form stable communities and to outcompete other species is based on its tolerance to the physiological stresses associated with diurnal submergence in tidal water, and reduced anoxic soils (Bertness 1991). As an intertidal plant, S. alterniflora may become completely submerged during a tidal event, depending on the marsh surface elevation and variable plant height throughout the growing season. Productivity within salt marshes is generally thought to be limited by nitrogen $(\mathrm{N})$ availability (Valiela \& Teal 1974), and the harsh physio-chemical conditions in the rhizosphere that may limit $\mathrm{N}$ uptake (King et al. 1982, Chambers et al. 1998).
Although intertidal salt marsh grasses may be submerged for several hours per day with water containing bioavailable $\mathrm{N}$, the extent to which shoot $\mathrm{N}$ uptake (leaf + stem) from the water column contribute to $\mathrm{N}$ demand is unknown. Subtidal seagrasses assimilate $\mathrm{N}$ through their shoots, although uptake varies dramatically among species. For example, shoot uptake of $\mathrm{N}$ can account for $50 \%$ of plant $\mathrm{N}$ demand in Thalassia testudinum (Lee \& Dunton 1999) and Thalassia hemprichii (Stapel et al. 1996). At the extreme, Phyllospadix torreyi can satisfy $100 \%$ of its $\mathrm{N}$ demand through foliar uptake since its roots act solely as an anchor (Terrados \& Williams 1997). The contribution of shoot $\mathrm{N}$ uptake to plant $\mathrm{N}$ demand is largely dependent on $\mathrm{N}$ concentration in the overlying water column (Stapel et al. 1996). Although nutrient concentrations may be one to several orders of magnitude greater in the sediments than in the water col- 
umn (Burdige \& Zheng 1998, McGlathery et al. 2001), shoot uptake may be a more energetically efficient alternative. Similar anaerobic conditions in the rhizosphere can also limit root $\mathrm{N}$ uptake in Spartina alterniflora (Bradley \& Morris 1990, Chambers et al. 1998, Mendelssohn \& Morris 2000); thus, shoot uptake may be an adaptation of intertidal salt marsh plants.

Flume studies in Atlantic Coast marshes have demonstrated that salt marsh ecosystems are predominantly a net sink for $\mathrm{NH}_{4}{ }^{+}, \mathrm{NO}_{3}{ }^{-}$, and $\mathrm{NO}_{2}{ }^{-}$(Wolaver 1981, Wolaver \& Zieman 1984, Wolaver et al. 1984, Whiting et al. 1989, Childers et al. 1993), and that they can also be a source (Wolaver et al. 1984, Childers et al. 1993) or sink (Wolaver \& Zieman 1984, Childers et al. 1993) of dissolved organic nitrogen (DON). Wolaver \& Zieman (1984) showed that $\mathrm{N}$ removal from flooding tides could supply up to $100 \%$ of the N needed to support the biomass in tall-form Spartina alterniflora and 30 to $105 \%$ of the $\mathrm{N}$ needed for intermediate-form $S$. alterniflora in a Virginia (USA) salt marsh; however, the contribution of shoot uptake to removal was not investigated. The study of Bouma et al. (2002) is frequently cited as showing that shoot uptake by Spartina anglica can, at most, contribute $\sim 10 \%$ to plant $\mathrm{N}$ demand. This estimate was based on the premise that plants were only submerged for $2.4 \mathrm{~h} \mathrm{~d}^{-1}$ and that uptake rates were constant and did not vary over time with substrate concentrations. The limited periods of tidal inundation reported by Bouma et al. (2002) may be attributed to the fact that Northern European salt marshes are typically high in elevation (French \& Reed 2001) and are inundated only during the highest stages of a tidal cycle. North American Atlantic coast tidal marshes generally have elevations that are decimeters below mean high tide (MHT), and periods of inundation can vary greatly depending on the tidal range and location within the marsh platform (Morris et al. 2005). For example, estimates from Drake et al. (2008) indicate that tall $S$. alterniflora in Massachusetts is inundated nearly every tide and may be submerged for 8.9 $\mathrm{h} \mathrm{d}^{-1}$, whereas the short form is infrequently inundated and only for $\sim 3.0 \mathrm{~h} \mathrm{~d}^{-1}$ when averaged over both spring and neap cycles.

We investigated the potential contribution of shoot (leaves + stems) $\mathrm{N}$ uptake from tidal water to plant $\mathrm{N}$ demand in mid-Atlantic Spartina alterniflora. We measured uptake rates of ${ }^{15} \mathrm{NH}_{4}{ }^{+},{ }^{15} \mathrm{NO}_{3}{ }^{-}$, and ${ }^{15} \mathrm{~N}$-glycine separately for both stem and leaf tissues to determine the uptake kinetics of inorganic and organic $\mathrm{N}$ in shoots. We then created a numerical model to estimate how shoot $\mathrm{N}$ uptake may satisfy the seasonal $\mathrm{N}$ demand of $S$. alterniflora using modeled vegetation growth and inundation, long-term water quality data, and experimentally determined uptake rates.

\section{MATERIALS AND METHODS}

Study sites. The field study was conducted within the Virginia Coast Reserve (VCR) Long-Term Ecological Research (LTER) Site in a salt marsh near Oyster, Virginia, between the Oyster Harbor $(\mathrm{OH})$ and Ramshorn Channel Creek (RC). Long-term nutrient concentration data were available for these two sites and for Cob Mill Creek (CM). Together, $\mathrm{CM}, \mathrm{OH}$, and $\mathrm{RC}$ represent a nutrient gradient representing mainland salt marshes that receive terrestrial groundwater inputs to low nutrient lagoonal salt marshes. Salt marshes along the eastern shore of Virginia are predominantly meso-tidal, and the tidal range at Oyster Harbor is $\sim 1.5 \mathrm{~m}$. Field experiments to determine in situ $\mathrm{N}$ uptake rates were conducted on intermediate growth form $(60-130 \mathrm{~cm})$ Spartina alterniflora between 12-14 June, 2007. Plants were $56.3 \pm 0.8 \mathrm{~cm}$ tall at the time of $\mathrm{N}$ treatment, and attained a height of $\sim 100 \mathrm{~cm}$ by the end of the growing season (August).

Plant $\mathbf{N}$ assimilation rates. Methods were adapted from Bouma et al. (2002). Nitrogen uptake experiments were conducted daily between 10:00 and 14:00 h to minimize any potential diel variation. This time period corresponded to low tide and allowed us to flood the plants artificially and uniformly. Each experimental unit consisted of an in situ mesocosm $(2.7 \pm 0.1$ plants mesocosm $^{-1}$ ) where plants were artificially flooded. A $15 \times 15.25 \mathrm{~cm}$ (length $\times$ internal diameter, i.d.) section of PVC was placed around the Spartina alterniflora plants and inserted into the sediment to a depth of $\sim 5 \mathrm{~cm}$. An agar solution $\left(15 \mathrm{~g} \mathrm{l}^{-1}\right)$ just above solidification temperature $\left(\sim 36^{\circ} \mathrm{C}\right)$ was poured into the PVC collar to a depth of $\sim 5 \mathrm{~cm}$. Immediately following the addition of agar, a tall, clear acrylic cylinder, $(100 \times 10 \mathrm{~cm}$ i.d.) was immediately placed over the vegetation, through the unsolidified agar, and inserted $\sim 5 \mathrm{~cm}$ into the ground to prevent tipping. Solidified agar formed a seal from the soil surface, and the cylinder was filled with $10 \mathrm{l}$ of synthetic seawater $\left(24.99 \mathrm{~g} \mathrm{NaCl}_{2}, 4.16 \mathrm{~g}\right.$ $\mathrm{Na}_{2} \mathrm{SO}_{4}, 0.79 \mathrm{~g} \mathrm{KCl}, 11.3 \mathrm{~g} \mathrm{MgCl}_{2} \cdot 6 \mathrm{H}_{2} \mathrm{O}, 1.35 \mathrm{~g}$ $\mathrm{CaCl}_{2} \cdot 2 \mathrm{H}_{2} \mathrm{Ol}^{-1}$ ). This volume of water completely submerged the plants. Labeled ${ }^{15} \mathrm{~N}\left({ }^{15} \mathrm{NH}_{4} \mathrm{Cl},{ }^{15} \mathrm{NO}_{3}\right.$, and ${ }^{15} \mathrm{~N}$ glycine $\left(>99.8 \%{ }^{15} \mathrm{~N}\right)$; Cambridge Isotope Labs, Cambridge, MA) was added to the volume of water to adjust the starting $\mathrm{N}$ concentration to either $1,5,10$, or $100 \mu \mathrm{M}$. There were 60 individual replicate mesocosms ( $\mathrm{n}=5 \times 3 \mathrm{~N}$ treatments $\times 4 \mathrm{~N}$ concentrations). However, when leakage exceeded $10 \%$ of the initial volume, the replicate was discarded. This resulted in $n=4$ for several $\mathrm{N}$ treatment and concentration combinations and in a corrected total of 53 replicates that were used to determine $\mathrm{N}$ uptake rates. ${ }^{15} \mathrm{~N}$ depletion in the mesocosm, which was calculated as the total amount of ${ }^{15} \mathrm{~N}$ assimilated into the plants, never exceeded $5 \%$ of the 
starting concentration in any treatment. Control plants that were used to determine natural $\delta^{15} \mathrm{~N}$ were harvested daily throughout the duration of the experiment (15 plants $\mathrm{d}^{-1}$ ). Three plants were pooled together by part (leaf or stem), ground, and analyzed for ${ }^{15} \mathrm{~N}$ as described below. No change in $\delta^{15} \mathrm{~N}$ content was observed throughout the duration of the experiment, and mean ${ }^{15} \mathrm{~N}$ content of pooled samples $(\mathrm{n}=19)$ was used in the ${ }^{15} \mathrm{~N}$ uptake rate determination.

To ensure a well-mixed medium, each mesocosm was aerated using a battery powered pump. After $1.5 \mathrm{~h}$ exposure of plants to the labeled ${ }^{15} \mathrm{~N}$, the experiment was terminated with the removal of the tall acrylic cylinder. Plants were cut at the surface of the agar, and were immediately rinsed in the field in 3 successive 101 containers filled with identical synthetic seawater (no nutrients) to remove any adsorbed label. Spartina alterniflora was carefully blotted dry in the field, placed on ice, and transferred to the laboratory for processing. In the laboratory, plants were separated into leaf and stem portions, and freeze dried. Plant material was homogenized to a fine powder using a ball mill, and these samples were analyzed at the UC Davis Stable Isotope Facility on a Europa Integra continuous flow mass spectrometer for ${ }^{15} \mathrm{~N}$ determination.

$\mathrm{N}$ uptake rates were determined using the modified equations of Bouma et al. (2002), where:

$$
\begin{gathered}
\mathrm{N}_{\text {total }}=(\% \mathrm{~N} / 100) \times \mathrm{DM} \\
{ }^{15} \mathrm{~N}_{\text {assimilated }}=\left(\left[\%{ }^{15} \mathrm{~N}_{\text {trt }}-\%{ }^{15} \mathrm{~N}_{\text {control }}\right] / 100\right) \times \mathrm{N}_{\text {total }} \\
V_{\text {upt }}={ }^{15} \mathrm{~N}_{\text {assimilated }} /\left(\mathrm{DM} \times t_{\text {exp }}\right)
\end{gathered}
$$

where $N_{\text {total }}$ is the total amount of $N(g)$ in the leaf or stem sample; $\% \mathrm{~N}$ is the concentration of $\mathrm{N}$ in the leaf or stem sample ( $\mathrm{g} \mathrm{N} \mathrm{gDM}^{-1}$ ); DM is the dry mass ( $\mathrm{g}$ ) of the sample ${ }^{15} \mathrm{~N}_{\text {assimilated }}$ is the amount of ${ }^{15} \mathrm{~N}(\mathrm{~g})$ assimilated; $\%{ }^{15} \mathrm{~N}_{\text {trt }}$ is the ${ }^{15} \mathrm{~N}$ content (mass basis) after a $1.5 \mathrm{~h}$ exposure to ${ }^{15} \mathrm{~N}$ treatment; $\%{ }^{15} \mathrm{~N}_{\text {control }}$ is the ${ }^{15} \mathrm{~N}$ natural abundance (mass basis) in plants not exposed to ${ }^{15} \mathrm{~N}$ treatments; $V_{\text {upt }}\left(\mathrm{g} \mathrm{N} \mathrm{g} \mathrm{DW}^{-1} \mathrm{~h}^{-1}\right)$ is the uptake rate of ${ }^{15} \mathrm{~N}$ from flood water normalized to leaf or stem mass; and $t_{\exp }$ is the time of exposure to the ${ }^{15} \mathrm{~N}$ treatments $(1.5 \mathrm{~h})$. Our model does not incorporate translocation of $\mathrm{N}$ from leaf to stem due to the short time course of the experiment.

To model how uptake rates will change as a function of $\mathrm{N}$ concentration, maximum $\mathrm{N}$ assimilation rates $\left(V_{\max }\right)$ and the half-saturation constant $\left(K_{\mathrm{m}}\right)$ for $\mathrm{N}$ were determined from uptake rates calculated using Eq. (3), using Proc NLIN in SAS (Version 9.1, Cary). Parameter estimates were obtained using the measured uptake rates at each concentration in the Michaelis-Menten equation (Eq. 4). From these parameters, it is possible to estimate the $\mathrm{N}$ uptake rate at the $\mathrm{N}$ concentrations in the flood water (see Fig. 1).

$$
V=\left(V_{\max } \times \mathrm{S}\right) /\left(K_{\mathrm{m}}+\mathrm{S}\right)
$$

$V$ is the experimentally determined $\mathrm{N}$ uptake rate $(\mathrm{gN}$ $\mathrm{gDW}^{-1} \mathrm{~h}^{-1}$ ) at a given nutrient concentration, $\mathrm{S}$ ( $\mu \mathrm{mol}$ $\left.\mathrm{l}^{-1}\right), V_{\max }$ is the modeled maximum uptake rate $(\mathrm{g} \mathrm{N}$ $\mathrm{gDW}^{-1} \mathrm{~h}^{-1}$ ), and $K_{\mathrm{m}}$ is the experimentally determined half-saturation constant $\left(\mu \mathrm{mol} \mathrm{l}^{-1}\right)$.

A total of 250 plants was harvested in May and August 2006 to derive a relationship between plant height and shoot mass. Plant heights were between 7 and $40 \mathrm{~cm}(\mathrm{n}=95)$ in May, and between 23 and $98 \mathrm{~cm}$ ( $\mathrm{n}=155$ ) in August. We pooled both sampling dates to create a relationship between plant height and mass. A subsample $(n=160)$ of these plants was used to determine the allocation of leaf and stem plant mass in $20 \mathrm{~cm}$ intervals in 5 plant size classes: $0-20,0-40$, $0-60,0-80$, and $0-100 \mathrm{~cm}$. This allocation was used to estimate the fraction of the mass submerged when plants were only partially inundated.

To determine the ecological significance of shoot uptake, we constructed a numerical model that compares shoot uptake rates with total $\mathrm{N}$ demand as a function of flooding duration, bioavailable $\mathrm{N}\left(\mathrm{NH}_{4}{ }^{+}\right.$, $\left.\mathrm{NO}_{3}{ }^{-}, \mathrm{DON}\right)$ concentration in the water column, and vegetation growth. We calculated inundation duration, plant mass distributions (stem vs. leaf), and uptake rates for each of the 5 plant height categories (0-20, 21-40, 41-60, 61-80, and 81-100 cm). Since the elevation of the plants on the marsh platform directly influences patterns of inundation, we estimated the amount of $\mathrm{N}$ demand satisfied by shoot uptake for intermediate-form Spartina alterniflora at surface elevations of -20 and $+20 \mathrm{~cm}$ relative to MSL. These elevations correspond to the growth range of intermediate-form $S$. alterniflora at our study site, and roughly to the theoretical growth range predicted for a $1.5 \mathrm{~m}$ tidal range (Mckee \& Patrick 1988). We do not present estimates for shoot uptake for the tall form (>1.5 $\mathrm{m}$ in height) which grows at lower elevations along the creek bank because our allometric relationships between stem and leaf mass are only valid to a $100 \mathrm{~cm}$ height.

We determined periods of inundation by simulating water level $(W)$ through time $(t)$ with a simple sine function that represents tidal fluctuations:

$$
W(t)=A \sin \left(\frac{2 \pi}{\lambda} t\right)-\eta
$$

where $A$ represents half of the tidal range $(0.75 \mathrm{~m}), \lambda=$ $12.5 \mathrm{~h}$, and $\eta$ is the elevation of the marsh surface relative to MSL (m). In the model, plant height $(h)$ increases at a constant rate throughout the growing season (1.95 $\times 10^{-4} \mathrm{~m} \mathrm{~h}^{-1}$ ), which is equivalent to $1 \mathrm{~m}$ over the entire growing season (214 d). Inundation of a plant segment occurs when $W(t)$ exceeds the height of a given plant segment, and periods of inundation, $I(t)$, are evaluated hourly. Plants take up $\mathrm{N}$ from the water column at rates proportional to the concentration of $\mathrm{N}$ according to 

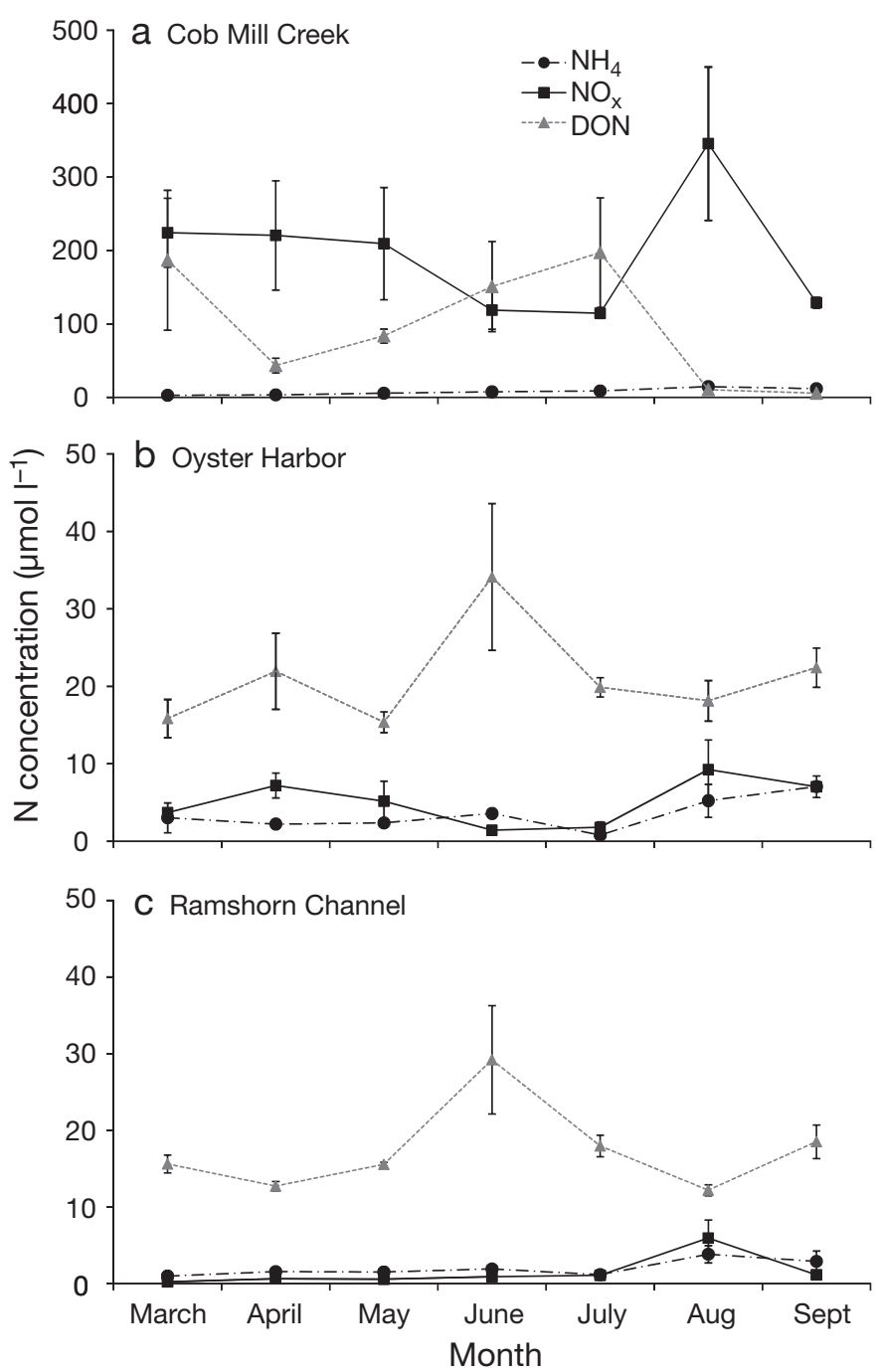

Fig. 1. $\mathrm{NH}_{4}{ }^{+}, \mathrm{NO}_{\mathrm{x}}$, and DON availability $\left(\mu \mathrm{mol} \mathrm{l}^{-1}\right.$; mean $\left.\pm \mathrm{SE}\right)$ for (a) Cob Mill Creek, (b) Oyster Harbor, and (c) Ramshorn Channel Creek from long-term water quality data (2004-2008) accessed from the LTER dataset VCR99057 and VCR08143. DON was estimated by subtracting $\mathrm{NH}_{4}{ }^{+}$and $\mathrm{NO}_{\mathrm{x}}$ data from reported total dissolved nitrogen (TDN) values

Eq. (3) (see Table 1), where $V_{\max }\left(\mathrm{g} \mathrm{N} \mathrm{g} \mathrm{shoot} \mathrm{mass}{ }^{-1}\right)$ is the uptake rate at saturation and $K_{\mathrm{m}}$ is the MichaelisMenten constant. We modeled the uptake of $\mathrm{NH}_{4}{ }^{+}$, $\mathrm{NO}_{3}{ }^{-}$, and DON in each segment of the plant according to separate values of $V_{\text {max }}$ for leaf and stem tissues, and long-term measurements of mean monthly concentrations of each $\mathrm{N}$ species along the mainland to the lagoonal marsh transect from 2004-2008 (VCR-LTER datasets VCR99057 and VCR08143; www.vcrlter.virginia.edu) (Fig. 1). The 3 sites represent a nutrient gradient from terrestrial groundwater $\mathrm{N}$ inputs to low nutrient, lagoonal salt marshes and thus reflect differences in $\mathrm{N}$ availability in the water column. Seasonal (March to October) mean water column $\mathrm{N}\left(\mathrm{NH}_{4}{ }^{+}+\right.$
$\mathrm{NO}_{3}{ }^{-}+$DON) concentrations were: $299 \pm 32,30 \pm 3$, and $21 \pm 2 \mu \mathrm{M}$ for $\mathrm{CM}, \mathrm{OH}$, and $\mathrm{RC}$ respectively. We assumed that plants can utilize only $\sim 20 \%$ of total DON (Tyler et al. 2003), and that glycine uptake rates are indicative of uptake of all DON species. Mozdzer et al. (2010) reported no significant differences in root DON uptake at 3 different DON treatments, and we assumed that this is the same for shoot uptake. To account for fractional DON availability, we adjusted values to be $20 \%$ of reported DON, lowering seasonal mean $\mathrm{N}$ concentrations to $223 \pm 29,13 \pm 2$, and $7 \pm$ $1 \mu \mathrm{M}$ plant available $\mathrm{N}$ in $\mathrm{CM}, \mathrm{OH}$, and $\mathrm{RC}$, respectively.

Following the approach of Bouma et al. (2002), the fraction of shoot $\mathrm{N}$ demand $(\gamma)$ that can be accommodated by shoot uptake can be expressed as:

$$
\gamma=\int^{t} \int^{h} \frac{I(h, t) \cdot B(h, t) \cdot V(h, t)}{b(h, t) \cdot C} \mathrm{~d} h \mathrm{~d} t
$$

where $B(h, t), I(h, t)$ and $V(h, t)$ represent the shoot mass, inundation duration, and $\mathrm{N}$ uptake rate at a particular height on the plant through time. The aboveground plant $\mathrm{N}$ demand is equal to the product of its growth rate $b\left(\mathrm{~g} \mathrm{~h}^{-1}\right)$ and the concentration of $\mathrm{N}, C$, within its tissues $(0.013 \mathrm{~g} \mathrm{~N}$ per $\mathrm{g}$ leaf and $0.074 \mathrm{~g} \mathrm{~N}$ per $\mathrm{g}$ stem). We explicitly calculated biomass and $\mathrm{N}$ uptake for stems and leaves in each plant height segment. Although we assumed that plant height increases linearly, with peak height and biomass being attained in September, our allometric relationships yielded a shoot mass that increases non-linearly throughout the growing season (Fig. 2). We then solved (6) numerically by calculating shoot uptake at the midpoint of each $20 \mathrm{~cm}$ plant segment in $1 \mathrm{~h}$ time steps.

\section{RESULTS}

\section{Plant N uptake}

In all treatments, leaves had greater uptake rates than stems per unit mass, and the greatest uptake rates were observed for $\mathrm{NH}_{4}{ }^{+}$, followed by DON and $\mathrm{NO}_{3}{ }^{-}$(Fig. 3). When the experimentally determined rates were fit to the Michaelis-Menten model, $V_{\max }$ for $\mathrm{NH}_{4}{ }^{+}$was 500 to $800 \%$ greater than that for $\mathrm{DON}$ or $\mathrm{NO}_{3}{ }^{-}$, respectively (Table 1). Leaf $\mathrm{N}$ uptake rates were 240 to $292 \%$ greater than stem uptake rates per unit mass within the same $\mathrm{N}$ treatment (Table 1), which may partly be attributed to a greater surface area:volume ratio.

\section{Plant mass and inundation time}

Mass allocation in stems and leaves varies greatly as a function of plant height (Table 2, Fig. 2). In plants up to $40 \mathrm{~cm}$ in height, $<35 \%$ of the mass was allocated to 


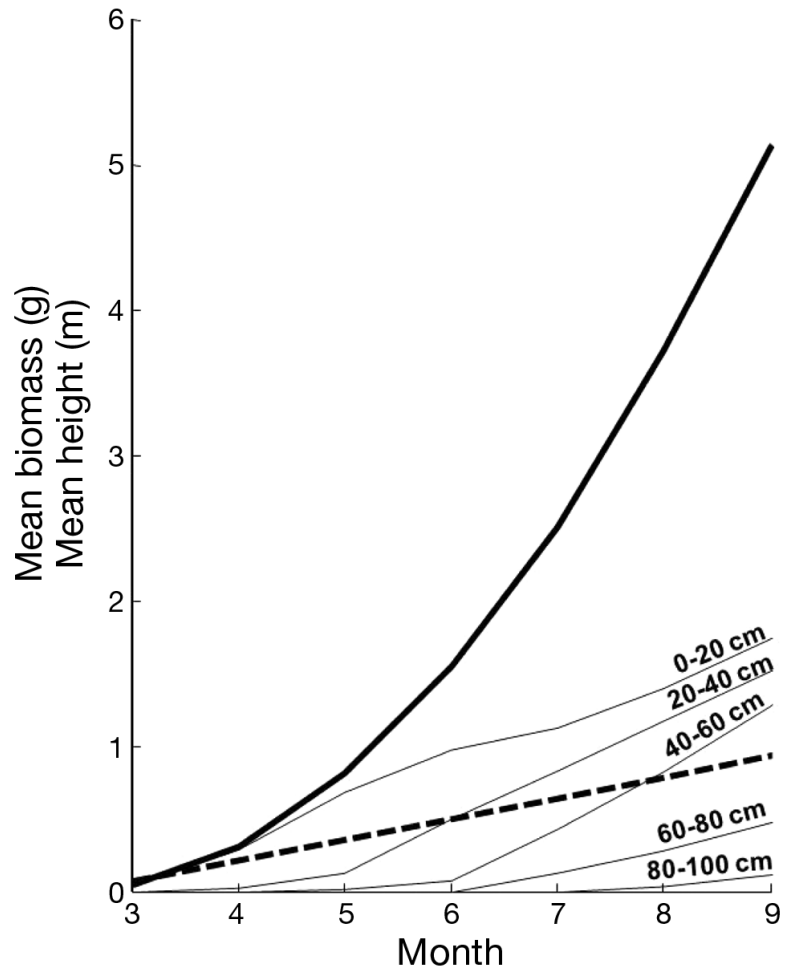

Fig. 2. Mean monthly total aboveground biomass (bold line) and plant height (dashed line) of Spartina alterniflora used to model $\mathrm{N}$ uptake rates and demand. In our model of plant growth, height increases linearly throughout the growing season, and estimates of biomass are derived from allometric relationships presented in Table 2 . The thin solid lines denote biomass in $20 \mathrm{~cm}$ segments of the plant, which were used to calculate uptake and demand during partial inundation
Table 1. Spartina alterniflora uptake parameters for $\mathrm{NH}_{4}{ }^{+}$, $\mathrm{NO}_{3}{ }^{-}$, and DON (glycine-N). Maximum uptake rate, $V_{\max }$ and the half saturation constant, $K_{\mathrm{m}}$, were determined by fitting the observed uptake rates to the Michaelis-Menten equation

\begin{tabular}{|lccccc|}
\hline $\begin{array}{l}\mathrm{N} \\
\text { treatment }\end{array}$ & Part & $\begin{array}{c}V_{\max } \\
\left(\mathrm{ng} \mathrm{N} \mathrm{g} \mathrm{DW}^{-1} \mathrm{~h}^{-1}\right)\end{array}$ & $\begin{array}{c}K_{\mathrm{m}} \\
\left.(\mu \mathrm{mol} \mathrm{N} \mathrm{l})^{-1}\right)\end{array}$ & $\mathrm{r}^{2}$ & $\mathrm{n}$ \\
\hline $\mathrm{NH}_{4}{ }^{+}$ & Leaf & $6903 \pm 1600$ & $33.1 \pm 21.6$ & 0.83 & 18 \\
& Stem & $2508 \pm 1101$ & $46.3 \pm 53.7$ & 0.72 & 18 \\
$\mathrm{NO}_{3}{ }^{-}$ & Leaf & $834 \pm 162$ & $9.6 \pm 6.0$ & 0.78 & 18 \\
& Stem & $343 \pm 90$ & $8.3 \pm 7.1$ & 0.72 & 18 \\
Glycine & Leaf & $1316 \pm 134$ & $9.7 \pm 3.7$ & 0.93 & 17 \\
& Stem & $449 \pm 103$ & $14.3 \pm 12.4$ & 0.71 & 17 \\
\hline
\end{tabular}

Table 2. Percent of total aboveground mass in each $20 \mathrm{~cm}$ segment of Spartina alterniflora. Plants were categorized into one of 5 height classes and by mean proportion of mass in stem and leaf per unit dry weight

\begin{tabular}{|lllrrrr|}
\hline \multirow{2}{*}{$\begin{array}{l}\text { Segment } \\
(\mathrm{cm})\end{array}$} & Part & \multicolumn{9}{c}{ \% biomass in each } & \multicolumn{3}{c}{ cm segment } \\
& & 20 & 40 & 60 & 80 & 100 \\
\hline $0-20$ & Stem & 28.7 & 33.6 & 43.0 & 31.9 & 26.7 \\
& Leaf & 71.3 & 57.5 & 20.1 & 8.9 & 7.2 \\
$21-40$ & Stem & & 0.0 & 2.8 & 14.6 & 16.1 \\
& Leaf & & 8.9 & 29.3 & 18.8 & 13.5 \\
$41-60$ & Stem & & & 0.0 & 2.3 & 10.8 \\
& Leaf & & & 4.8 & 17.3 & 14.2 \\
$61-80$ & Stem & & & & 0.0 & 0.0 \\
& Leaf & & & & 6.2 & 9.2 \\
$81-100$ & Stem & & & & & 0.0 \\
& Leaf & & & & & 2.2 \\
\hline
\end{tabular}

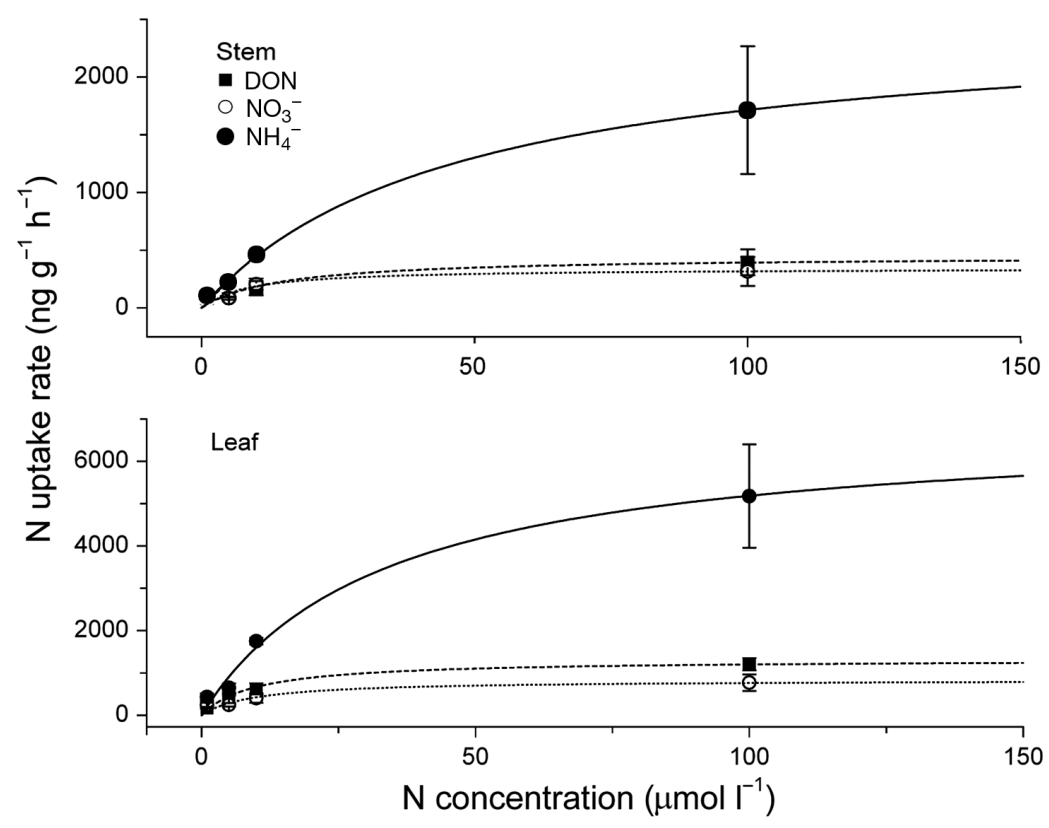

Fig. 3. Effects of ${ }^{15} \mathrm{~N}$ substrate and concentration on uptake rates (ng N g DW ${ }^{-1}$ $\mathrm{h}^{-1}$ ) on intact Spartina alterniflora plants. Reported values are mean $V_{\text {upt }} \pm \mathrm{SE}$. Plotted lines are uptake rates estimated from Michaelis-Menten kinetics the stem. However, as plant height increases, more mass is allocated to the stem to support the leaf mass. Allocation to stems increases to $46 \%$ for $41-60 \mathrm{~cm}$ tall plants, $48 \%$ for $61-80 \mathrm{~cm}$ tall plants, and $54 \%$ for $81-100 \mathrm{~cm}$ tall plants (Table 2). Inundation duration changes as a function of both plant height and relative elevation on the marsh platform (Fig. 4a,b). In the low marsh scenario (Fig. 4a), our model predicts that the lowest portions of the plant are submerged for $\sim 400 \mathrm{~h} \mathrm{mo}^{-1}$, or $\sim 6 \mathrm{~h} \mathrm{tide}^{-1}$. The time of inundation decreases as a function of segment height. Inundation hours total 300, 250, 200, and $100 \mathrm{~h} \mathrm{mo}^{-1}$ for segments of the plant that are 21-40, $41-60,61-80$, and $81-100 \mathrm{~cm}$ above the marsh surface. When Spartina alterniflora grows to a meter in height, plants are completely submerged for only $3.3 \mathrm{~h}$ tide $^{-1}$, but $<3 \%$ of the plant's mass occurs at the tallest segment (Table 2). 


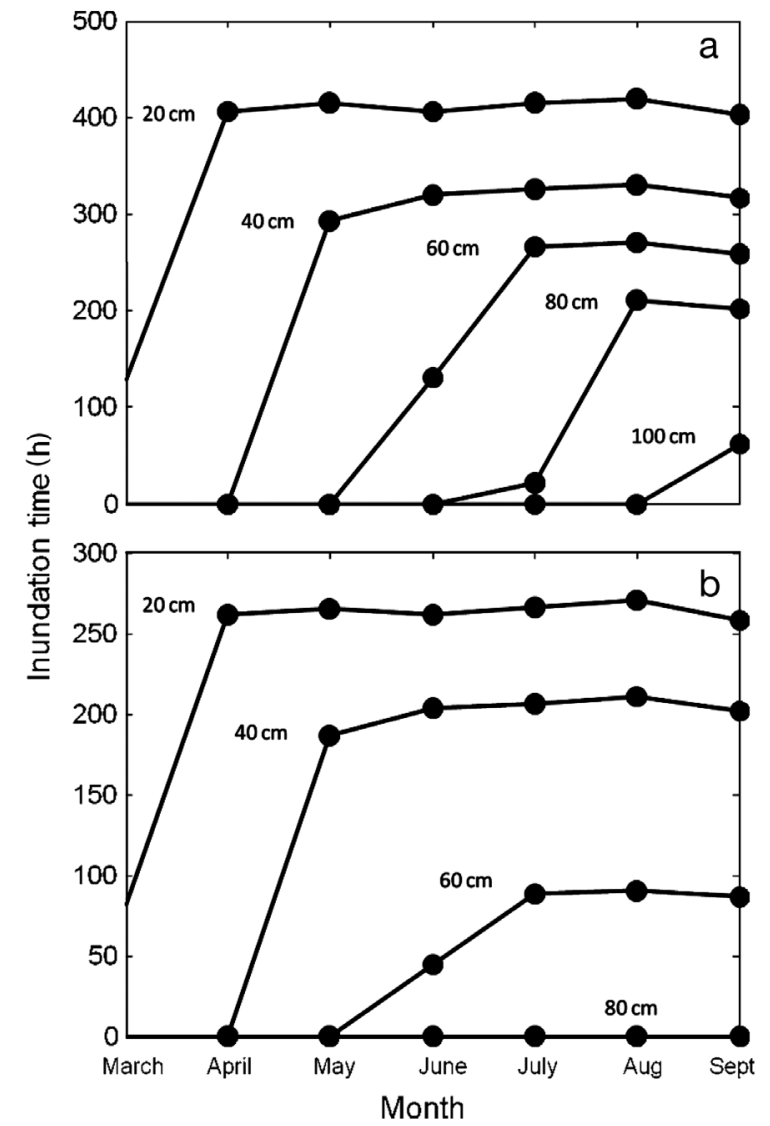

Fig. 4. Monthly predicted inundation time (h) for each $20 \mathrm{~cm}$ segment in intermediate-form Spartina alterniflora plants at elevations (relative to MSL) of (a) -20 , and (b) $+20 \mathrm{~cm}$

Increases in marsh elevation result in a decreased average inundation time, assuming the same growth rate and structure. In the high elevation scenario (Fig. 4b), inundation times for the $0-20$ and $21-40 \mathrm{~cm}$ segments are reduced by $>40 \%$ to 250 and $200 \mathrm{~h} \mathrm{mo}^{-1}$, respectively, and by $60 \%$ in the $41-60 \mathrm{~cm}$ segment to $<100 \mathrm{~h} \mathrm{mo}^{-1}$.

\section{Model predictions}

In our low elevation scenario at ambient field $\mathrm{N}$ concentrations, the contribution of shoot (leaves + stem) N uptake decreases with decreasing water column $\mathrm{N}$ concentrations. Shoot N uptake has the potential to account for up to $22 \%$ of monthly plant $\mathrm{N}$ demand in $\mathrm{CM}$ (high $\mathrm{N}$ ), $16 \%$ in $\mathrm{OH}$ (middle $\mathrm{N}$ ), and $9 \%$ in $\mathrm{RC}$ (low N) (Fig. 5). The total aboveground plant $\mathrm{N}$ demand that can be attributed to shoot uptake (total $\mathrm{g}$ $\mathrm{N}$ from shoot uptake:total $\mathrm{g} \mathrm{N}$ shoot mass) averaged over the growing season was highest in CM (15\%), intermediate in $\mathrm{OH}(10 \%)$, and lowest in $\mathrm{RC}(5 \%)$. Overall, the contribution of shoot uptake to satisfy

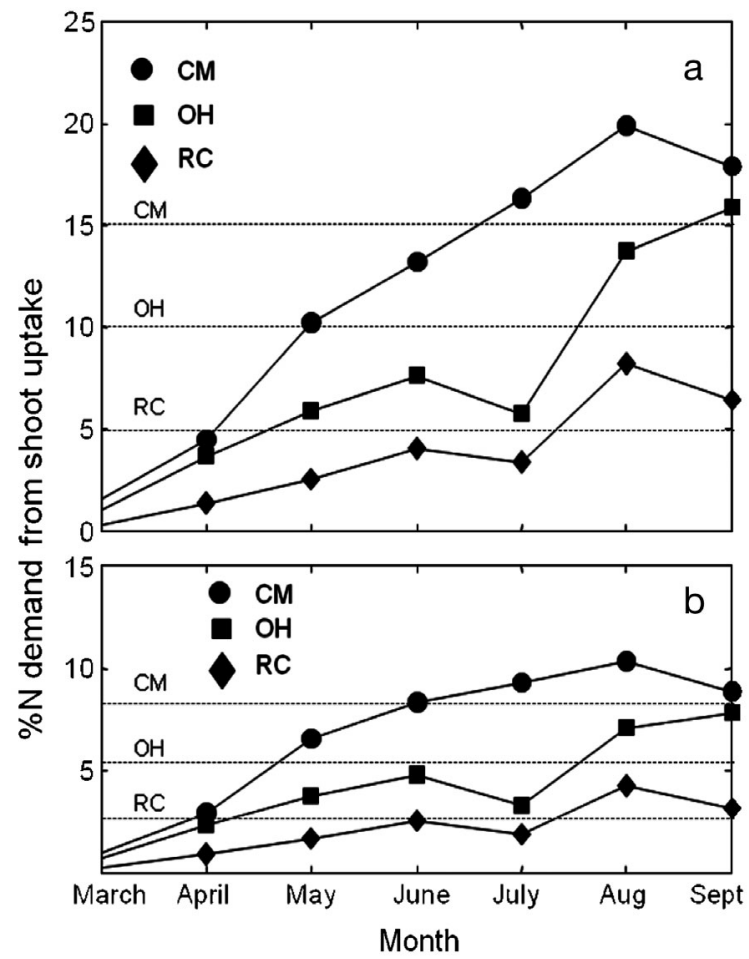

Fig. 5. Predicted monthly contribution to Spartina alterniflora $\mathrm{N}$ demand satisfied by shoot uptake in the salt marsh at the Cobb Mill Creek (CM), Oyster Harbor (OH), and Ramshorn Channel Creek (RC) (high, middle, and low N respectively) sites at (a) -20 , and (b) $+20 \mathrm{~cm}$ MSL. Dashed horizontal lines indicate the mean growing season $\mathrm{N}$ demand (total $\mathrm{g} \mathrm{N}$ from shoot uptake:total $\mathrm{g} \mathrm{N}$ shoot mass) that can be attributed to shoot uptake at each site

plant $\mathrm{N}$ demand is proportional to the availability of water column nutrients. For example, when $\mathrm{NH}_{4}{ }^{+}$concentrations dropped in July at the $\mathrm{OH}$ and $\mathrm{RC}$ sites (Fig. 1), so did the contribution of $\mathrm{NH}_{4}{ }^{+}$to plant $\mathrm{N}$ demand (Fig. 6a). Although water column nutrients may be elevated at the beginning of the growing season (Fig. 1), shoot uptake does not make a significant contribution to $\mathrm{N}$ demand at this time since mass is insufficient to support uptake (Fig. 2).

Shoot $\mathrm{N}$ uptake was primarily driven by water column $\mathrm{NH}_{4}{ }^{+}$concentration because uptake rates for $\mathrm{NH}_{4}{ }^{+}$were $4 \times$ greater than those for $\mathrm{NO}_{3}{ }^{-}$or DON (Fig. 6a-c). The contribution of shoot uptake varied with decreasing $\mathrm{N}$ availability from the $\mathrm{CM}$ to the $\mathrm{OH}$ and finally to the RC site (Figs. 1 \& 5a). Over the growing season, shoot $\mathrm{NH}_{4}{ }^{+}$uptake alone could satisfy $8 \%$ of plant $\mathrm{N}$ demand at the high nutrient site $\mathrm{CM}$ (Fig. 6a). In contrast, $\mathrm{NO}_{3}{ }^{-}$contributed least to plant $\mathrm{N}$ demand (4\%; Fig. 6c) although monthly mean $\mathrm{NO}_{3}{ }^{-}$concentrations in the flood water at $\mathrm{CM}$ (Fig. 1) exceeded Michaelis-Menten saturating concentrations (Table 1) by an order of magnitude. DON contributed a similar proportion of shoot $\mathrm{N}$ demand 

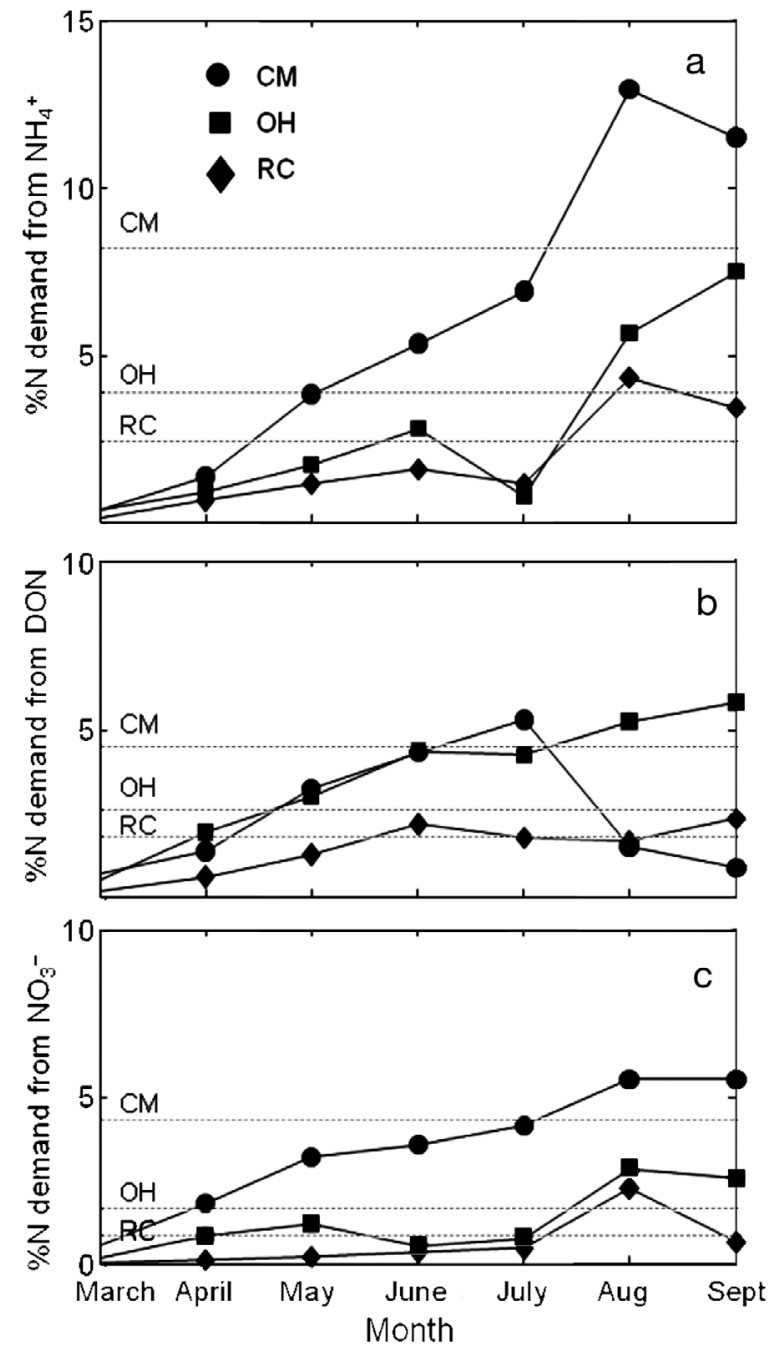

Fig. 6. Predicted monthly contribution to Spartina alterniflora $\mathrm{N}$ demand satisfied by shoot uptake of (a) $\mathrm{NH}_{4}{ }^{+}$, (b) DON, and (c) $\mathrm{NO}_{3}{ }^{-}$at the Cobb Mill Creek (CM), Oyster Harbor $(\mathrm{OH})$, and Ramshorn Channel Creek (RC) (high, middle, and low N respectively) sites at $-20 \mathrm{~cm}$ MSL. Dashed horizontal lines indicate the mean growing season $\mathrm{N}$ demand (total $\mathrm{g} \mathrm{N}$ from shoot uptake:total $\mathrm{g} \mathrm{N}$ shoot mass) that can be attributed to shoot uptake at each site

as $\mathrm{NO}_{3}^{-}$(Fig. 6b), although bioavailable concentrations were nearly an order of magnitude lower than that of $\mathrm{NO}_{3}^{-}$(Fig. 1).

With a $40 \mathrm{~cm}$ increase in elevation (from -20 to $+20 \mathrm{~cm}$ MSL), the relative importance of shoot uptake decreased by $>60 \%$ (Fig. 5b). The decreased contribution of shoot uptake to seasonal plant $\mathrm{N}$ demand (8\% of plant $\mathrm{N}$ demand in $\mathrm{CM}, 5 \%$ in $\mathrm{OH}$, and $3 \%$ in $\mathrm{RC}$ ) is solely attributed to shorter periods of inundation. The seasonal patterns in $\mathrm{N}$ uptake are identical to those described above. However, the reduction in contribution is attributed to lower periods of inundation due to a higher position on the marsh platform (Fig. 4).

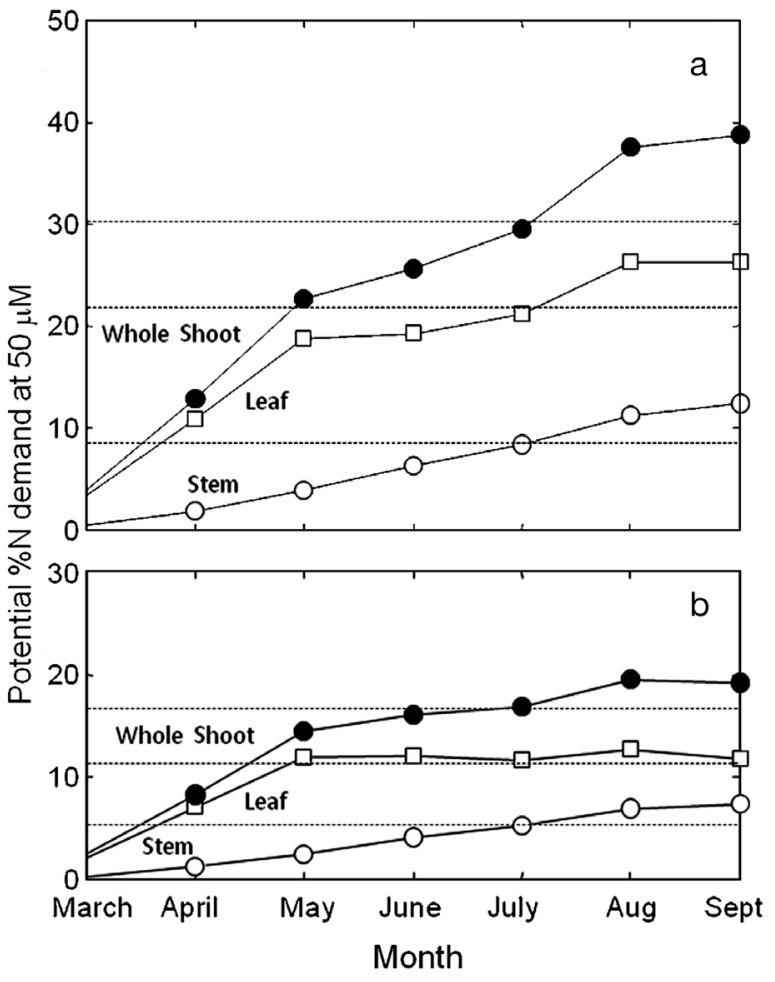

Fig. 7. Potential contribution to $\mathrm{N}$ demand satisfied by $\mathrm{N}$ uptake by whole shoot, leaf and stem tissues of Spartina alterniflora ( $\mathrm{N}$ uptake rates at $V_{\max }$ ) at (a) $-20 \mathrm{~cm}$ and (b) $+20 \mathrm{~cm}$ MSL. Dashed horizontal lines indicate the mean growing season $\mathrm{N}$ demand (total $\mathrm{g} \mathrm{N}$ from shoot uptake/total $\mathrm{g} \mathrm{N}$ shoot mass) that can be attributed to shoot uptake at each site

Leaf uptake is responsible for $\sim 70 \%$ of total shoot uptake under both elevation scenarios assuming uptake at $50 \mu \mathrm{M} \mathrm{N}$ (Fig. 7a,b). The greater contribution from leaf tissues may be attributed to the greater $\mathrm{N}$ uptake rates in leaves than in stems (Table 1, Fig. 7a,b). Although stems do not support high uptake rates, Spartina alterniflora stems still contribute $\sim 30 \%$ of total shoot uptake (Fig. 7).

\section{DISCUSSION}

Our model predicts that shoot uptake at ambient field concentrations has the potential to provide up to $15 \%$ of a plant's seasonal aboveground $\mathrm{N}$ demand in mid-Atlantic salt marshes under natural conditions. These estimates are up to $50 \%$ greater than previously reported for Spartina anglica from a eutrophic marsh (Bouma et al. 2002). Even at our most N-limited site $(7 \pm 1 \mu \mathrm{M} \mathrm{N})$, shoot uptake by $S$. alterniflora potentially supplied $5 \%$ of plant $\mathrm{N}$ demand, which is similar to the estimate of Bouma et al. (2002) for their most eutrophic site $(156 \pm 11 \mu \mathrm{M} N)$. For $S$. alterniflora in Virginia, the importance of shoot uptake is dependent on both the 
elevation of the plants on the marsh platform, which affects the time of inundation, and available $\mathrm{N}$ (specifically $\mathrm{NH}_{4}^{+}$) concentrations in the flooding water. Specifically, assuming marshes of similar elevation and tidal range, our model results suggest that shoot uptake has the potential to supply $34 \%$ of plant $\mathrm{N}$ demand in eutrophic estuaries ( $\geq 50 \mu \mathrm{M}$ N) (Fig. 7). The conclusion that shoot uptake by $S$. anglica can supply at most $10 \%$ of $\mathrm{N}$ demand in a high-N estuarine system was based on the assumptions that flood water $\mathrm{N}$ concentrations were low when mass was great enough to sustain significant $\mathrm{N}$ uptake rates, and that inundation time was $<2.4 \mathrm{~h} \mathrm{~d}^{-1}$ (Bouma et al. 2002). We came to a different conclusion for $S$. alterniflora although $\mathrm{N}$ uptake rates were about half of those reported for $S$. anglica. Our differences in the potential contribution from shoot uptake can be attributed to differences in plant inundation time, where partial inundation may vary from $12 \mathrm{~h} \mathrm{~d}^{-1}$ in April to $\sim 3.3 \mathrm{~h} \mathrm{~d}^{-1}$ of complete submergence in September. Modeling $\mathrm{N}$ uptake on partially submerged plants is critical since $S$. alterniflora is only submerged for $\sim 1.7 \mathrm{~h}$ high tide ${ }^{-1}$ even late in the growing season when plants grow to heights of $\sim 100 \mathrm{~cm}$. However, at this height, $>88 \%$ of a single $S$. alterniflora shoot has the potential to take up $\mathrm{N}$ for $\sim 8 \mathrm{~h} \mathrm{~d}^{-1}$.

Both the water column $\mathrm{N}$ concentrations and the form of the available $\mathrm{N}$ influence the potential significance of shoot $\mathrm{N}$ uptake. $\mathrm{NH}_{4}{ }^{+}$uptake is the predominant process in satisfying shoot $\mathrm{N}$ demand, although concentrations of $\mathrm{NH}_{4}{ }^{+}$in the water column are lower than those of other $\mathrm{N}$ species. A similar pattern is seen in seagrasses where shoot $\mathrm{N}$ uptake is largely dependent on $\mathrm{NH}_{4}{ }^{+}$concentrations in the water column $\left(\mathrm{NH}_{4}{ }^{+}\right.$comprises $>80 \% \mathrm{~N}$ taken up) (Stapel et al. 1996). Assuming similar proportional availability of $\mathrm{N}$, DON uptake constitutes the second greatest contribution to plant $\mathrm{N}$ demand. Although water column $\mathrm{NO}_{3}{ }^{-}$ concentration may be an order of magnitude greater than the concentration needed to saturate the uptake kinetics, $\mathrm{NO}_{3}^{-}$uptake rates and the contribution of $\mathrm{NO}_{3}{ }^{-}$are the lowest. This may be attributed to the relatively high energetic cost of assimilating and reducing $\mathrm{NO}_{3}{ }^{-}$(Lambers et al. 1998). The energetic cost of using $\mathrm{NO}_{3}{ }^{-}$may be too high given the availability of DON and $\mathrm{NH}_{4}{ }^{+}$in the water column and in the rhizosphere. This low uptake rate of $\mathrm{NO}_{3}{ }^{-}$may explain why Drake et al. (2008) concluded that foliar uptake was not an important process in a ${ }^{15} \mathrm{NO}_{3}{ }^{-}$enrichment experiment in a New England salt marsh. While large amounts of $\mathrm{NO}_{3}{ }^{-}$may not be effectively removed from the water column by Spartina alterniflora shoot uptake ( $<4 \%$ total $\mathrm{N}$ demand), our results suggest that $\mathrm{NH}_{4}{ }^{+}$ and DON may be removed this way. Our results also suggest that DON uptake can account for almost $30 \%$ of shoot $\mathrm{N}$ uptake at ambient nutrient concentrations in a relatively unpolluted Mid-Atlantic salt marsh. This finding is proportionally similar to estimates that root DON uptake can account for $24 \%$ of plant $\mathrm{N}$ demand in S. alterniflora (Mozdzer et al. 2010). Other studies have also shown that DON contributes substantially to macroalgal (Tyler et al. 2005, Tyler \& McGlathery 2006), and seagrass (Vonk et al. 2008) N demand. In a scenario of estuarine eutrophication, the magnitude of the potential growth response will ultimately depend on the source, species, and concentration of allochthonous N. For example, riverine and groundwater inputs dominated by $\mathrm{NO}_{3}{ }^{-}$will unlikely benefit $S$. alterniflora production as suggested in the $\mathrm{NO}_{3}{ }^{-}$fertilization experiment in Massachusetts (Drake et al. 2008). Atmospheric $\mathrm{N}$ deposition, including wet and dry deposition $\left(\mathrm{NH}_{4}{ }^{+}\right.$, urea, and amino acids) may enhance shoot uptake due to the greater uptake potential of these $\mathrm{N}$ sources. The relative contribution of atmospheric $\mathrm{N}$ to salt marshes is quite variable, and can supply 1 to $40 \%$ of plant $\mathrm{N}$ demand (Hopkinson \& Giblin 2008). Changes in land use may also alter allochthonous $\mathrm{N}$ inputs. For example, decadal-scale data suggest that water column $\mathrm{N}$ concentrations are increasing, with the greatest increases being in the form of DON (Verity 2002). Assuming that these increases in DON and $\mathrm{NH}_{4}{ }^{+}$will continue in the future, shoot $\mathrm{N}$ uptake may become a more important process in satisfying plant $\mathrm{N}$ demand.

Marsh elevation and plant height are factors that determine the importance of shoot uptake. Our data also suggest that the enhanced productivity of both tall and intermediate growth form Spartina alterniflora may also be potentially attributed to shoot uptake of nutrients from the water column. Morris et al. (2002) reported a biomass optimum that increases with decreasing elevation to a certain threshold in $S$. alterniflora. We suggest that the higher productivity at lower elevation within a marsh (more frequently inundated) may also be partly attributed to shoot uptake of $\mathrm{N}$ from the water column. Beyond the elevation threshold, there is likely to be a tradeoff between the potential for shoot $\mathrm{N}$ uptake, and reduced photosynthetic capacity due to tidal inundation (Kathilankal et al. 2008). With increases in elevation on the marsh platform, the relative importance of shoot uptake decreases by almost $50 \%$, suggesting that root uptake, controlled by physio-chemistry in the rhizosphere (Bradley \& Morris 1991, Chambers et al. 1998), may become the predominant source of $\mathrm{N}$. This transition at the higher elevation also corresponds to a change in plant phenotype from intermediate to the infrequently inundated short growth form S. alterniflora.

Biomass partitioning favors shoot uptake in low elevation Spartina alterniflora. Plants from lower por- 


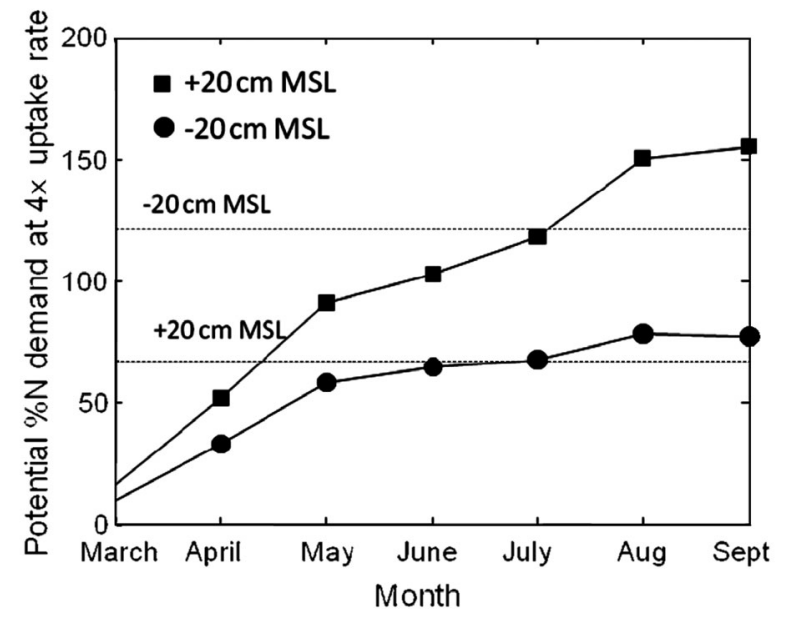

Fig. 8. Potential contribution to Spartina alterniflora N demand satisfied by $\mathrm{N}$ uptake in a eutrophic (50 $\mu \mathrm{MN})$ brackish estuary. Low salinity is assumed to increase $\mathrm{N}$ uptake rates 4 -fold. Dashed horizontal lines indicate the mean growing season $\mathrm{N}$ demand (total $\mathrm{g} \mathrm{N}$ from shoot uptake:total $\mathrm{g} \mathrm{N}$ shoot mass) that can be attributed to shoot uptake at each elevation

tions of the marsh tend to have lower root:shoot ratios (Gallagher 1974, Dame \& Kenny 1986). One interpretation may be a greater investment in shoot mass when $\mathrm{N}$ can be easily taken up from an aerobic water column. Maintaining roots in an anaerobic environment is energetically costly and influences estuarine species zonation (Maricle et al. 2006). Hence, shoot N uptake may explain differences in root:shoot ratios in different $S$. alterniflora growth forms along the marsh platform.

Changes in salinity and nutrient availability may also affect shoot uptake. For example, Bouma et al. (2002) observed a $400 \%$ increase in leaf $\mathrm{NH}_{4}{ }^{+}$uptake rates in brackish salt marshes of lower salinity (18.5) compared to salt marshes of higher salinity (31) in the Netherlands. In our model simulations, we assumed that Spartina alterniflora N uptake rates remain constant over naturally occurring ranges of salinity. However, salt marshes are exposed to a range of salinities that may vary with location in the estuary and proximity to freshwater input. Assuming a similar 400\% increase in leaf $\mathrm{NH}_{4}{ }^{+}$uptake rates alone in brackish salt marshes, and uptake rates measured at $50 \mu \mathrm{M} \mathrm{N}$ (representing a eutrophic estuary), our model indicates that shoot uptake of $\mathrm{N}$ can satisfy between 66 and $151 \%$ of seasonal aboveground plant demand depending on marsh elevation (Fig. 8). While these estimates need to be verified experimentally, the ability of plants to adapt to their environment suggests that rates of shoot $\mathrm{N}$ uptake can be enhanced significantly in brackish environments to satisfy nearly all $S$. alterniflora $\mathrm{N}$ demand.

\section{CONCLUSIONS}

We suggest that shoot uptake of $\mathrm{N}$ from the water column is a substantial source of $\mathrm{N}$ for Spartina alterniflora. Annual estimates of aboveground plant $\mathrm{N}$ demand acquired by shoot uptake for $S$. alterniflora (5 to $15 \%$ for this site) fall between the range for terrestrial plants $(<10 \%)$ (Wilson 1992, Boyce et al. 1996, Tomaszewski et al. 2003) and seagrasses (50 to 100\%) (Stapel et al. 1996, Terrados \& Williams 1997, Peuke et al. 1998, Vonk et al. 2008). However, when our data and model are applied to brackish, eutrophic systems, shoot uptake appears to have the potential to meet 66 to $>100 \%$ of plant $\mathrm{N}$ demand. The contribution of shoot uptake is directly proportional to the time of inundation (a function of marsh elevation and plant height), available $\mathrm{N}$ concentrations, and salinity, which may vary with location of the marsh in an estuary. Our results also suggest that the aboveground canopy of $S$. alterniflora may be an effective filter for removing nutrients from the water column, similar to seagrass dominated ecosystems.

Acknowledgements. We thank B. Curtis and R. Baker for help in the field, and A. Mills and P. D'Odorico for helpful insights. Funding for this study was from the South Atlantic Chapter of the Society of Wetland Scientists to T.J.M., NSF LTER grant DEB 0621014, and the USGS Global Change Research Program. Reference herein to any specific commercial products, processes or services by trade name, trademark, manufacturer or otherwise, does not necessarily constitute or imply its endorsement, recommendation or favoring by the US Government or its employees.

\section{LITERATURE CITED}

Bertness MD (1991) Zonation of Spartina patens and Spartina alterniflora in a New England salt marsh. Ecology 72: $138-148$

Bouma TJ, Stapel J, van der Heiden J, Koutstaal B, van Soelen J, van Ijzerloo L (2002) Relative importance of macrophyte leaves for nitrogen uptake from flood water in tidal salt marshes. Mar Ecol Prog Ser 240:93-104

Boyce RL, Friedland AJ, Chamberlain CP, Poulson SR (1996) Direct canopy nitrogen uptake from ${ }^{15} \mathrm{~N}$-labeled wet deposition by mature red spruce. Can J Forest Res 26: 1539-1547

Bradley PM, Morris JT (1990) Influence of oxygen and sulfide concentration on nitrogen uptake kinetics in Spartina alterniflora. Ecology 71:282-287

Bradley PM, Morris JT (1991) The influence of salinity on the kinetics of $\mathrm{NH}_{4}{ }^{+}$uptake in Spartina alterniflora. Oecologia 85:375-380

Burdige DJ, Zheng SL (1998) The biogeochemical cycling of dissolved organic nitrogen in estuarine sediments. Limnol Oceanogr 43:1796-1813

> Chambers RM, Mozdzer TJ, Ambrose JC (1998) Effects of salinity and sulfide on the distribution of Phragmites australis and Spartina alterniflora in a tidal saltmarsh. Aquat Bot 62:161-169 
Childers DL, Cofershabica S, Nakashima L (1993) Spatial and temporal variability in marsh-water column interactions in a southeastern USA salt marsh estuary. Mar Ecol Prog Ser 95:25-38

Dame RF, Kenny PD (1986) Variability of Spartina alterniflora primary production in the euhaline North Inlet estuary. Mar Ecol Prog Ser 32:71-80

Drake DC, Peterson BJ, Deegan LA, Harris LA, Miller EE, Warren RS (2008) Plant nitrogen dynamics in fertilized and natural New England salt marshes: a paired ${ }^{15} \mathrm{~N}$ tracer study. Mar Ecol Prog Ser 354:35-46

French JR, Reed DJ (2001) Physical contexts for salt marsh conservation. In: Warren A, French JR (eds) Habitat conservation: managing the physical environment. Wiley, Chichester, p 179-228

Gallagher JL (1974) Sampling macro-organic matter profiles in salt marsh plant root zones. Soil Sci Soc Am J 38: $154-155$

Hopkinson CS, Giblin AE (2008) Nitrogen dynamics of coastal salt marshes. In: Capone DG, Bronk DA, Mulholland MR, Carpenter EJ (eds) Nitrogen in the marine environment, 2nd edn. Academic Press, San Diego, p 991-1036

Kathilankal JC, Mozdzer TJ, Fuentes JD, D'Odorico P, McGlathery KJ, Zieman JC (2008) Tidal influences on carbon assimilation by a salt marsh. Environ Res Lett 3: 044010 doi:10.1088/1748-9326/3/4/044010

King GM, Klug MJ, Wiegert RG, Chalmers AG (1982) Relation of soil-water movement and sulfide concentration to Spartina alterniflora production in a Georgia salt marsh. Science 218:61-63

Lambers H, Chapin FS, Pons TL (1998) Plant physiological ecology. Springer, New York

Lee KS, Dunton KH (1999) Inorganic nitrogen acquisition in the seagrass Thalassia testudinum: development of a whole-plant nitrogen budget. Limnol Oceanogr 44: $1204-1215$

Maricle BR, Crosier JJ, Bussiere BC, Lee RW (2006) Respiratory enzyme activities correlate with anoxia tolerance in salt marsh grasses. J Exp Mar Biol Ecol 337:30-37

McGlathery KJ, Berg P, Marino R (2001) Using porewater profiles to assess nutrient availability in seagrass-vegetated carbonate sediments. Biogeochemistry 56:239-263

Mckee KL, Patrick WH (1988) The relationship of smooth cordgrass (Spartina alterniflora) to tidal datums: a review. Estuaries 11:143-151

Mendelssohn IA, Morris JT (2000) Eco-physiological controls on the productivity of Spartina alterniflora Loisel. In: Weinstein MP, Kreeger DA (eds) Concepts and controversies in tidal marsh ecology. Kluwer, Dordrecht, p 59-80

Mitsch WJ, Gosselink JG (1993) Wetlands, 2nd edn. Van Nostrand Reinhold, New York, NY

Morris JT, Sundareshwar PV, Nietch CT, Kjerfve B, Cahoon DR (2002) Responses of coastal wetlands to rising sea level. Ecology 83:2869-2877

Morris TJ, Porter D, Neet M, Noble PA, Schmidt L, Lapine LA, Jensen JR (2005) Integrating LIDAR elevation data, multispectral imagery and neural network modelling for marsh characterization. Int J Remote Sens 26:5221-5234

Mozdzer TJ, Zieman JC, McGlathery KJ (2010) Nitrogen

Editorial responsibility: Kenneth Heck Jr.,

Dauphin Island, Alabama, USA uptake by native and invasive temperate coastal macrophytes: importance of dissolved organic nitrogen. Estuaries Coasts 33:784-797

Pennings SC, Bertness MD (2001) Salt marsh communities. In: Bertness MD, Gaines SD, Hay ME (eds) Marine community ecology. Sinauer, Sunderland, MA, p 289-316

> Peuke AD, Jeschke WD, Dietz KJ, Schreiber L, Hartung W (1998) Foliar application of nitrate or ammonium as sole nitrogen supply in Ricinus communis. I. Carbon and nitrogen uptake and inflows. New Phytol 138:675-687

> Stapel J, Aarts TL, van Duynhoven BHM, de Groot JD, van den Hoogen PHW, Hemminga MA (1996) Nutrient uptake by leaves and roots of the seagrass Thalassia hemprichii in the Spermonde Archipelago, Indonesia. Mar Ecol Prog Ser 134:195-206

Terrados J, Williams SL (1997) Leaf versus root nitrogen uptake by the surfgrass Phyllospadix torreyi. Mar Ecol Prog Ser 149:267-277

Tomaszewski T, Boyce RL, Sievering H (2003) Canopy uptake of atmospheric nitrogen and new growth nitrogen requirement at a Colorado subalpine forest. Can J Forest Res 33:2221-2227

Tyler AC, McGlathery KJ (2006) Uptake and release of nitrogen by the macroalgae Gracilaria vermiculophylla (Rhodophyta). J Phycol 42:515-525

Tyler AC, McGlathery KJ, Anderson IC (2003) Benthic algae control sediment-water column fluxes of organic and inorganic nitrogen compounds in a temperate lagoon. Limnol Oceanogr 48:2125-2137

- Tyler AC, McGlathery KJ, Macko SA (2005) Uptake of urea and amino acids by the macroalgae Ulva lactuca (Chlorophyta) and Gracilaria vermiculophylla (Rhodophyta). Mar Ecol Prog Ser 294:161-172

Valiela I, Teal JM (1974) Nutrient limitation in salt marsh vegetation. In: Reimold RJ, Queen WH (eds) Ecology of halophytes. Academic Press, New York, p 547-563

Verity PG (2002) A decade of change in the Skidaway River estuary. I. Hydrography and nutrients. Estuaries 25: 944-960

Vonk JA, Middelburg JJ, Stapel J, Bouma TJ (2008) Dissolved organic nitrogen uptake by seagrasses. Limnol Oceanogr 53:542-548

Whiting GJ, Mckellar HN, Spurrier JD, Wolaver TG (1989) Nitrogen exchange between a portion of vegetated salt marsh and the adjoining creek. Limnol Oceanogr 34: 463-473

Wilson EJ (1992) Foliar uptake and release of inorganic nitrogen compounds in Pinus sylvestris L. and Picea abies (L.) Karst. New Phytol 120:407-416

Wolaver TG (1981) Nitrogen and phosphorus exchange between a mesohaline marsh and the surrounding estuary. PhD dissertation, University of Virginia, Charlottesville

Wolaver TG, Zieman J (1984) The role of tall and medium Spartina alterniflora zones in the processing of nutrients in tidal water. Estuar Coast Shelf Sci 19:1-13

Wolaver TG, Johnson W, Marozas M (1984) Nitrogen and phosphorus concentrations within North Inlet, South Carolina - speculation as to sources and sinks. Estuar Coast Shelf Sci 19:243-255

Submitted: August 18, 2009; Accepted: March 7, 2010

Proofs received from author(s): June 28, 2011 